\title{
EXPERIMENTAL IN-VITRO BONE CEMENTS DISINTEGRATION WITH ULTRASONIC PULSATING WATER JET FOR REVISION ARTHROPLASTY
}

\author{
Sergej Hloch, Josef Foldyna, Frank Pude, Ján Kl'oc, Michal Zeleňák, Pavol Hvizdoš, \\ Peter Monka, Igor Smolko, Jiři Ščučka, Dražan Kozak, Aleksandar Sedmak, Emília Mihalčinová
}

Original scientific paper

The paper deals with the study of using the selective property of ultrasonic pulsating water jet for the disintegration of the interface created by bone cement between cemented femoral stem and trabecular bone tissue as a potential technique for revision arthroplasty. Six types of commercial bone cements based on Polymethyl Methacrylate were used for investigation. The cements were mixed using the DePuy - SmartMix ${ }^{\circledR}$ CTS / vacuum mixing bowl. Mechanical properties of hardened bone cements were determined by nanoindentation. The bone cement samples were disintegrated using the pulsating water jet technology. The water pressure varied between $8 \div 20 \mathrm{MPa}$. A circular nozzle with an orifice diameter of 0,7 mm was used for water jetting. The stand-off distance from the target material was $2 \mathrm{~mm}$ and the traverse speed $1 \mathrm{~mm} / \mathrm{s}$. The volume of material removal and depth of created traces were measured by MicroProf FRT optical profilometer. The results positively support an assumption that pulsating water jet has a potential to be a suitable technique for the quick and safe disintegration of bone cement during revision arthroplasty.

Keywords: bone cement; revision arthroplasty; ultrasonic pulsating water jet

\section{Eksperimentalna in-vitro razgradnja koštanog cementa pomoću ultrazvučnog pulzirajućeg mlaza vode za potrebe revizijske artroplastike}

Izvorni znanstveni članak

Članak obuhvaća studiju uporabe ultrazvučnog pulzirajućeg mlaza vode odabranih svojstava za razgradnju veze ostvarene pomoću koštanog cementa između cementiranog bedrenog drška i trabekularnog koštanog tkiva, kao potencijalne tehnike za revizijsku artroplastiku. Šest tipova komercijalnog koštanog cementa baziranog na polimetil metakrilatu rabljeni su za ovo istraživanje. Cementi su miješani uz pomoć DePuy - SmartMix® CTS / vakumske zdjele za miješanje. Mehanička svojstva ojačanog koštanog cementa određena su nanoindentacijom. Uzorci koštanog cementa su razgrađeni primjenom tehnologije pulzirajućeg mlaza vode. Tlak vode se mijenjao između 8 i $20 \mathrm{MPa}$. Kružna mlaznica s promjerom otvora od 0,7 mm je rabljena za rezanje mlazom vode. Odstojanje od ciljanog materijala bilo je $2 \mathrm{~mm}$, a poprečna brzina iznosila je $1 \mathrm{~mm} / \mathrm{s}$. Volumen odstranjenog materijala i dubina kreiranih tragova mjereni su pomoću MicroProf FRT optičkog profilometra. Rezultati pozitivno podupiru pretpostavku da pulzirajući mlaz vode ima potencijal biti odgovarajuća tehnika za brzu i sigurnu razgradnju koštanog cementa pri revizijskoj artroplastici.

Ključne riječi: koštani cement; revizijska artroplastika; ultrazvučni pulzirajući mlaz vode

\section{Introduction}

Removal of bone cement during revision arthroplasty is a very important factor of this surgical technique. More than $20 \%$ of all arthroplasties will need to be revised due to aseptic loosening, recurrent dislocation, infection or periprosthestic fracture. Revision arthroplasty has less favourable outcomes than primary. The removal of bone cement from the femoral canal extends over certain amount of time, which heightens the risk of complications, i.e. the risk of bone damage and even the danger of unsuccessful reimplantation of a new prosthesis. The extraction efficiency of cemented femoral stem depends on the technique, applied technologies, the material and nursing care (Fig. 1). Each prosthesis consists of femoral and acetabular components. The femoral component is inserted in the femur and bone cement forms the interface between the bone and bone cement. During hip replacement surgery, the bone cement must be disintegrated and then removed the femoral component is removed. Cemented endoprosthesis is inserted in the femoral channel. Mechanical properties of the femoral stem are determined by the type of material (titanium, stainless steel).

Many authors have studied the opportunities of bone cement removal from the femoral canal. To date a number of techniques have been tested to reduce the perioperative adverse events of total hip arthoplasty. The application of high-energy waves was studied by May et al. [1] and
Weinstein et al. [2] Schrerus et al. [3], Braun et al. [4], Stranne et al. [5], whilst Schmidt et al. [6], [7] studied extracorporeal shock wave lithotriptor. Segmental cement extraction was examined by Chin et al. [8], Schurman et al. [9], Ekelund et al. [10] and Jingushi et al. [11].

Ballistically driven chiselling system was investigated by Porsch et al. [12], Holmenschlager et al. [13], Piatek et al. [14], and Toth et al. [15]. Szendroi et al. [16] studied options of retrograde stem removal.

Many techniques for creating femoral windows have been described by Witt et al. [17], Hackenbroch et al. [18], Weber et al. [19], Tyer et al. [20], Moreland et al. [21]. To obtain access to entire distal cement, distal fenestration and expansion of trochanteric osteotomy or the transfemoral approach, the authors Younger et al. [22], Chen et al. [23], Miner et al. [24] investigated the use of extended osteotomy. To reduce the cortical window and extended trochanteric osteotomy disadvantages, the authors Goto et al. [26] studied cement-in-cement techniques. This technique is characterized by removing part of old bone cement, with a new prosthesis then being inserted. New bone cement is added to the old, and the stem is fixed in the femoral canal. Cement-in-cement technique has been introduced to reduce intraoperative complications during and after the revision of fixed cemented stem. Some good preliminary results have been reported, but the perforation and fracture of the femur were recorded. 
The next investigation area was the applications of lasers. The authors Buchelt et al. examined the application of laser for the disintegration of PMMA. Braren et al. [27] demonstrated the use of excimer laser for the material removal of bone cement, but in experiments this tool was very slow. Scholz et al. [28] found that carbon dioxide laser showed the best effect, but is currently used rarely. Caillouette et al. [29], deSteiger et al. [31] and Smith et al. [32] described a new ultrasonically-driven tool for the removal of bone cement. The author hit at the need for a cooling and sucking system. The first opportunities for PMMA bone cement removal by water jet were described by Honl et al. [33]. Prof. Honl dealt with the use of water jet as a new tool for endoprosthesis revision surgery. Opportunities for the use of both plain and abrasive water jet as a cutting tool were investigated in study [34, 35, 36].

\section{Experimental arrangement}

The removal of bone cement during revision arthroplasty [37] is a very important aspect of the surgical technique. Bone cement removal has been studied by many authors and many techniques were developed in order to enhance bone cement removal during endoprostheses replacement.
The long-term success of the reimplanted endoprosthesis lies in the applied surgical techniques as well as the material which creates an interface between the femoral stem and trabecular bone tissue. During revision surgery, taking in account other factors (Fig. 1), many problems and complications occur such as cracks of bone and loosing biological potential. Mentioned issues are caused by the mechanical and thermal damage of bone tissue during classical technique surgery. Above described methods for the removal of bone cement include high-speed drills, chisels, saws, and reamers, which are often associated with the fracture or perforation of the femoral shaft. The removal of bone cement from the femoral canal takes a certain amount of time, and carries the risk of complications, thus risking bone damage and perhaps even endangering the successful reimplantation of a new prosthesis. Therefore the aim of the study is the experimental testing of a technique with low technological level set up, in order to simplify the introduction of a non-destructive, cold technique to the orthopedic field. In our experiment commercial PMMA bone cement samples were disintegrated using the pulsating water jet technology. The effect of water pressure on the volume of material removal and depth of created traces was investigated in particular.

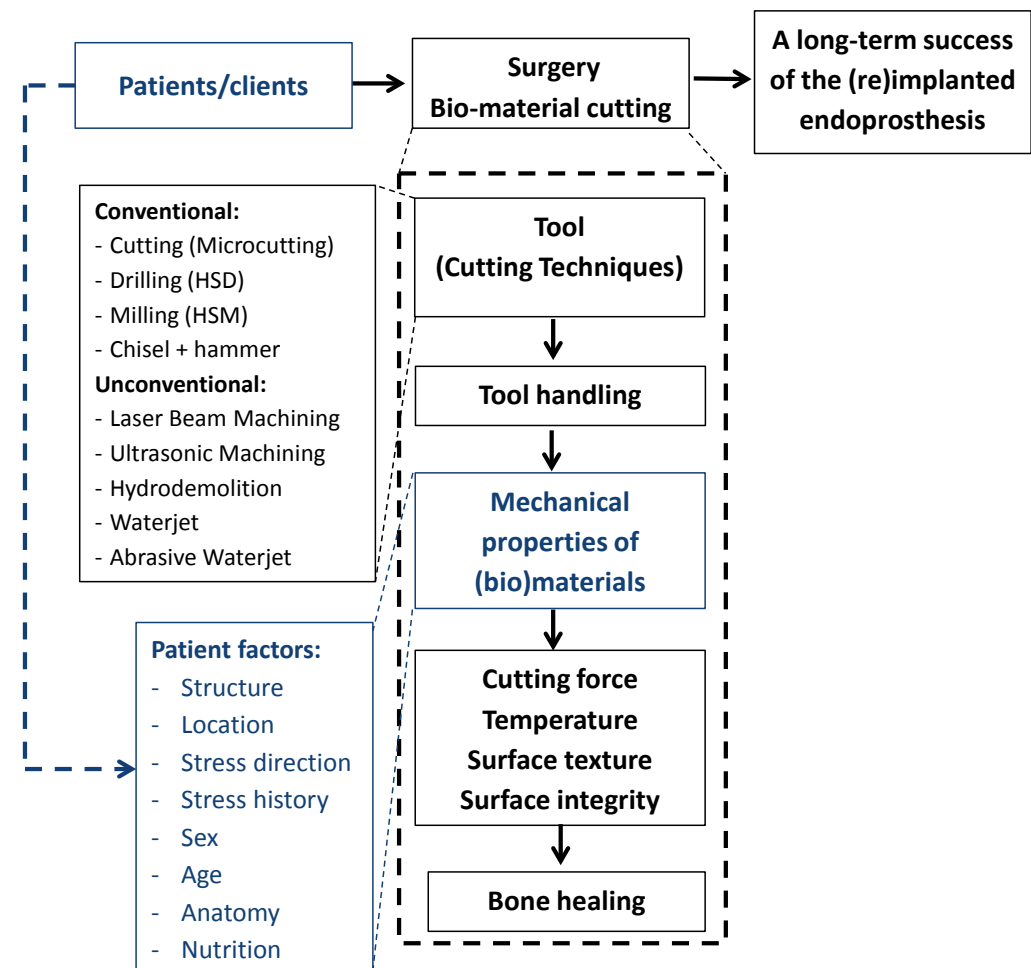

Figure 1 Scheme of factors affecting the long term success of re-implanted cemented femoral stem after revision surgery

\section{Experiment}

In order to investigate the possible use of water jet technology and the modifications thereof, bone cement samples were disintegrated using pulsating water jet. The tests were performed at the Institute of Geonics of the CAS in Ostrava. The technological set up consisted of a plunger pump Hammelmann HDP 253, and robot ABB IRB 6640-180 for handling the pulsating water head (Figs. 2 and 3). As a source of acoustic waves for the generation of pulsating water jet, an Ecoson WJ-UG 63040 generator specially designed for pulsating water jetting tools was used. The MVT circular nozzle with an orifice diameter of $0,7 \mathrm{~mm}$ was used for water jetting. The standoff distance from the target material was $2 \mathrm{~mm}$. The traverse speed was $1 \mathrm{~mm} / \mathrm{s}$. The pump pressure varied between $8 \div 20 \mathrm{MPa}$. The technological conditions of the tests are summarized in Tab. 1. Experiments were performed with pulsating water jet with the modulation frequency of $41,9 \mathrm{kHz}$ 


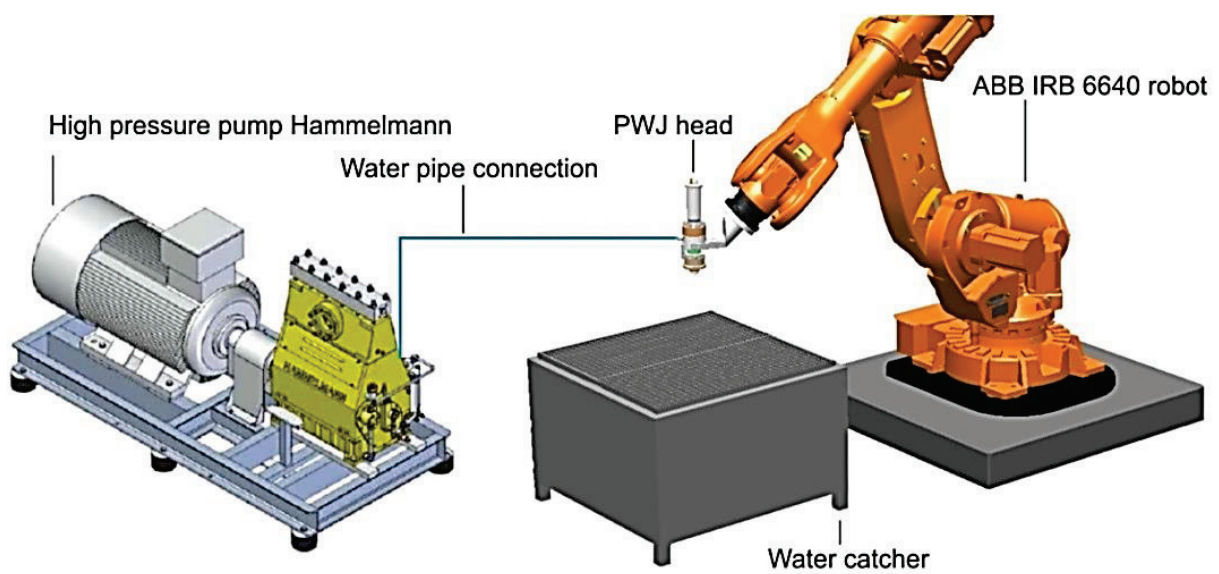

Figure 2Experimental configuration of high pressure pulsating water jet system

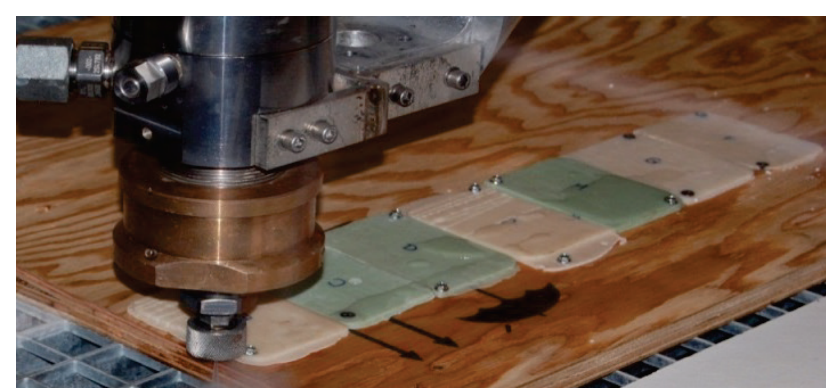

Figure3 Disintegration experiment on bone cement samples

Table 1Experimental set up
\begin{tabular}{|l|c|c|c|c|}
\hline Pressure $p(\mathrm{MPa})$ & 8 & 12 & 16 & 20 \\
\hline Water flow rate 1/min & 2,05 & 2,51 & 2,89 & 3,24 \\
\hline Orifice type & \multicolumn{5}{|c|}{ Circular (MVT) } \\
\hline Orifice diameter $d(\mathrm{~mm})$ & \multicolumn{4}{|c|}{2} \\
\hline Stand-off $z(\mathrm{~mm})$ & \multicolumn{4}{|c|}{1} \\
\hline Traverse speed $v(\mathrm{~mm} / \mathrm{s})$ & \multicolumn{4}{|c|}{$41,90 \mathrm{kHz}$} \\
\hline Modulation frequency kHz & \multicolumn{4}{c|}{} \\
\hline
\end{tabular}

6 types of PMMA bone cement were investigated. The cement samples were prepared by manual mixing under vacuum in a DePuy vacuum bowl in strict compliance with the manufacturer's instructions. Microscopic preparations (polished sections) were prepared from the bone cements for assessment of their physical properties. The sections were polished down to a roughness of $0,1 \mu \mathrm{m}$. Size and volume of bubble pores in hardened bone cements were measured using image analysis methods. Nanoindentation measurements were performed on the polished sections with a TTX-NHT nanoindentation tester (CSM Instruments, Switzerland). A Berkovich pyramid diamond tip was used in simple monotonic mode with maximum loading of $10 \mathrm{mN}$. Loading and unloading rate was $20 \mathrm{mN} / \mathrm{min}$, the hold time at maximum was $10 \mathrm{~s}$. The resulting load-penetration depth (P-h) curves were evaluated according to the analysis of Oliver and Pharr [38]. The results of mechanical properties estimation on hardened bone cement samples by the nanoindentation are shown in Tab. 2. The volume of material removal from the surface area of $4 \times 4 \mathrm{~mm}$ was measured and the depth of created traces was determined using the MicroProf FRT profilometer. The mean depth of a cutting trace was calculated as an arithmetical average of 1000 values measured along the trace.

\section{Results and discussion}

The results of the bone cement disintegration tests are graphically illustrated in Figs. 4, 5, 6 and 7.

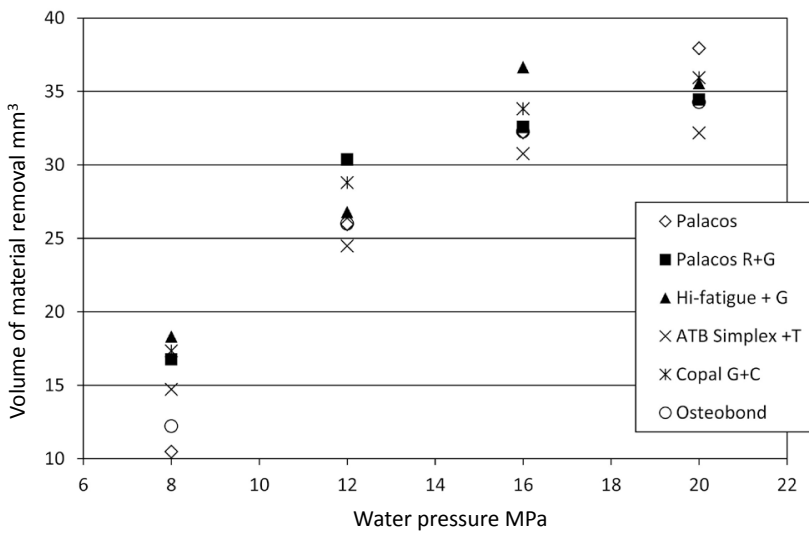

Figure 4 Material removal volume at various values of water pressure for the tested bone cement samples

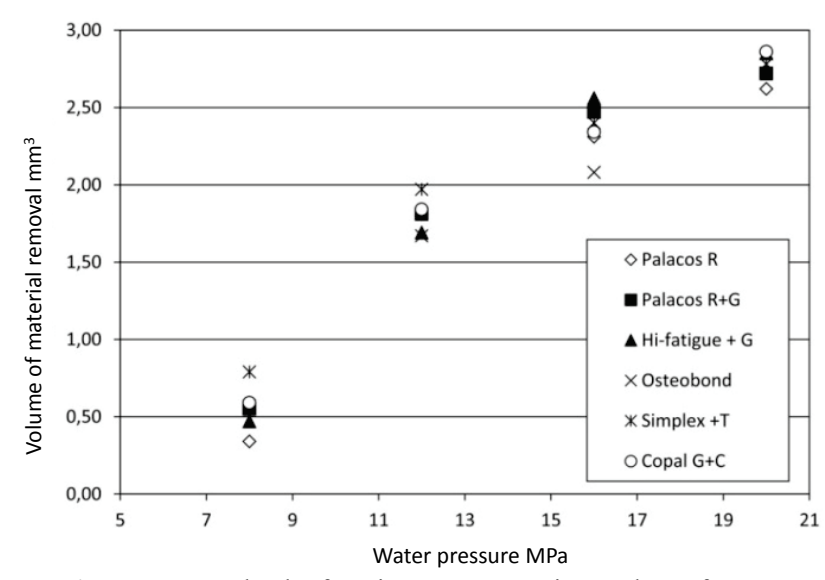

Figure 5 Mean depth of cutting traces at various values of water pressure for the tested bone cement samples

Values of the material removal volume rise significantly with increasing water pressure (Fig. 4). An increase in water pressure from 8 to $20 \mathrm{MPa}$ can cause more than three times higher values of material removal (see the Palacos sample in Fig. 4). There are no strong differences between particular cement types. It corresponds to the mechanical properties of the bone cements, which have similar values for all tested samples (Tab. 2). Dependence of the mean depth of cutting trace 
Table 2 Mechanical properties of tested bone cements $\left(H_{\mathrm{it}}-\right.$ nanoindentation hardness, MPa; $E_{\mathrm{it}}$ - modulus of elasticity, GPa)

\begin{tabular}{|c|c|c|c|c|c|c|}
\hline Name & Pores vol. / \% & Pore size $/ \mu \mathrm{m}$ & $H_{\text {it }} / \mathrm{MPa}$ & $\mathrm{St} \mathrm{dev}$ & $E_{\text {it }} / \mathrm{GPa}$ & $\mathrm{St}$ dev \\
\hline \multirow{3}{*}{ Palacos R } & 0,3 & 7,8 & 293,7 & 3,9 & 4,71 & 0,13 \\
\cline { 2 - 7 } & 0,7 & 10,8 & 300,4 & 23,4 & 4,96 & 0,67 \\
\cline { 2 - 7 } & 3,5 & 14,0 & 294,6 & 5,8 & 4,48 & 0,08 \\
\hline \multirow{3}{*}{ Palacos R+G } & 12,0 & 25,0 & 331,9 & 35,5 & 4,72 & 0,34 \\
\cline { 2 - 7 } & 5,4 & 20,7 & 324,1 & 7,4 & 4,74 & 0,05 \\
\cline { 2 - 7 } & 10,1 & 24,9 & 286,1 & 6,9 & 4,51 & 0,31 \\
\hline \multirow{3}{*}{ Hi-fatigue +G } & 10,3 & 22,0 & 286,6 & 11,9 & 4,48 & 0,09 \\
\cline { 2 - 7 } & 5,4 & 20,8 & 309,3 & 14,7 & 4,84 & 0,20 \\
\hline \multirow{3}{*}{ Osteobond } & 4,6 & 20,0 & 283,2 & 8,6 & 4,50 & 0,15 \\
\cline { 2 - 7 } & 2,7 & 14,6 & 295,4 & 21,6 & 4,45 & 0,28 \\
\cline { 2 - 7 } & 2,0 & 16,0 & 284,5 & 11,4 & 4,62 & 0,18 \\
\hline \multirow{3}{*}{ ATB Simplex +T } & 0,8 & 16,8 & 301,6 & 5,0 & 4,72 & 0,20 \\
\cline { 2 - 7 } & 1,4 & 14,0 & 320,6 & 35,1 & 4,80 & 0,21 \\
\cline { 2 - 7 } & 1,7 & 17,8 & 289,8 & 9,6 & 4,48 & 0,12 \\
\hline & 2,8 & 20,3 & 291,7 & 10,8 & 4,66 & 0,08 \\
\cline { 2 - 7 } & 4,4 & 24,9 & 358,7 & 50,7 & 4,72 & 0,38 \\
\cline { 2 - 7 } & 7,6 & 27,4 & 285,4 & 6,2 & 4,51 & 0,12 \\
\hline
\end{tabular}

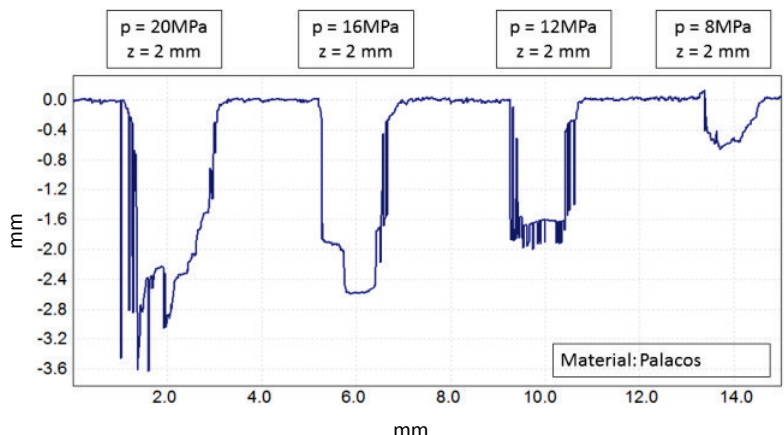

a)

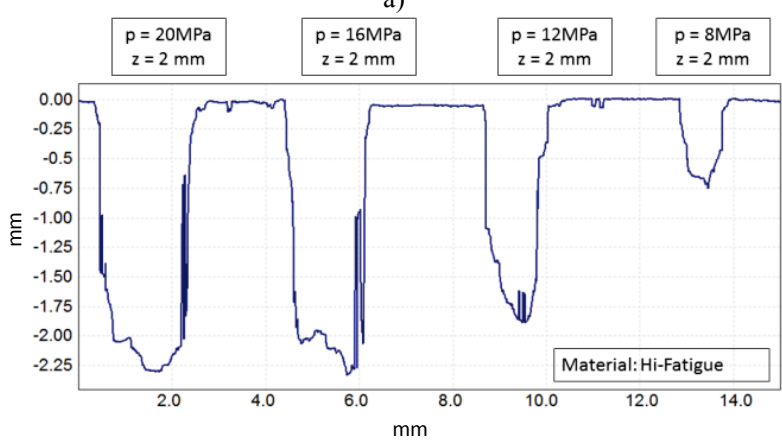

c)

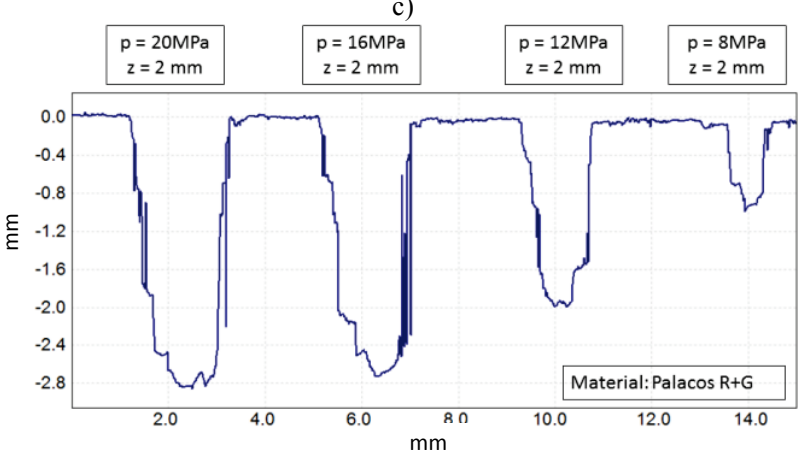

b)

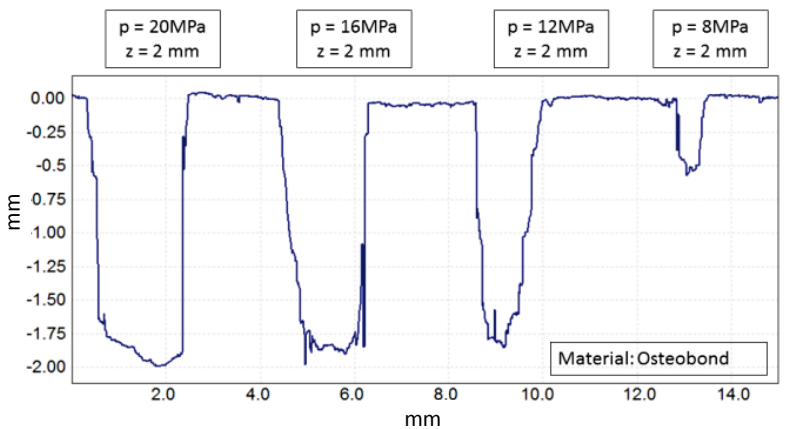

d)

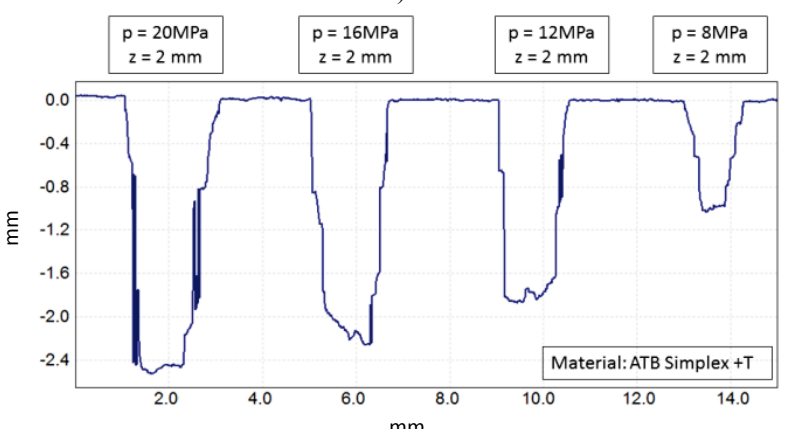

e)

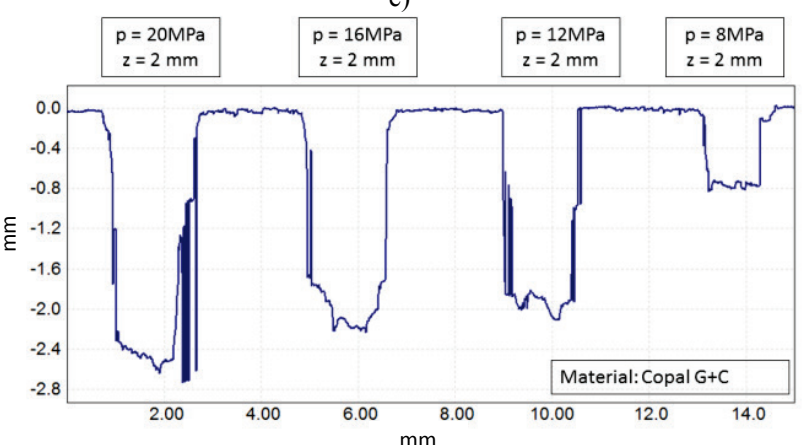

f)

Figure 6 Typical cross-sections of disintegrated bone cement samples - profiles obtained by MicroProf FRT profilometer: a) Palacos; b) Palacos R+G; c) Hi-fatigue + G; d) Osteobond; e) ATB Simplex + T; f) Copal G + C

on the water pressure shows a similar increasing trend (Fig. 5). The depth of created grooves ranges between 0,5 and $2,8 \mathrm{~mm}$ and the differences between the tested bone cement samples are not significant. The character of traces created by the pulsating water jet is illustrated in
Figs. 6 and 7. The traces have ragged bottom and sides. The cross-section profile shape mostly evokes an isosceles or scalene trapezium. 


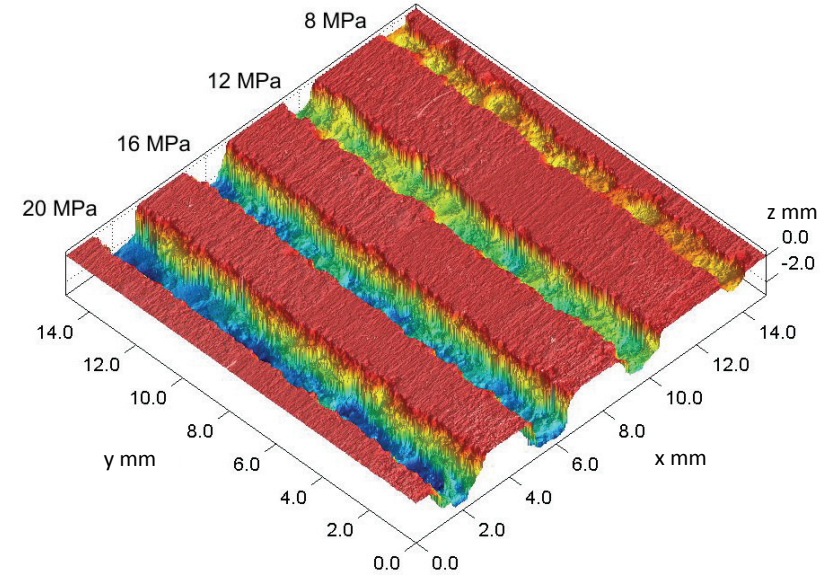

Figure 7 ATB Simplex + T sample after water jetting - surface 3D profile obtained by MicroProf FRT profilometer

\section{Conclusion}

Based on experiments it can be concluded that the pulsating water jet represents a potentially suitable technology for bone cement removal due to the relatively low pressures necessary for disintegration of the bone cement. Next research will be focused on pulsating water jet disintegration effects on bone cements under changing technological conditions, such as traverse speed, stand-off distance, number of passes, frequency of pulses and nozzle orifice diameter.

The aim is to decrease costs and any potential undesirable clinical impacts connected with the use of this method for the targeted destruction of bone cement during revision surgery. The presented experimental results are relevant for further investigation in order to rationalize the (re)implantation of femoral stems to reduce the thermal effect of bone cement. In such a way the biological potential of bone during surgery can be retained, and by eliminating the negative effects a patient can sooner return to normal life.

Innovation of the exerted surgical procedures with utilization of the water jet in medicine is a vision to the near future with solid foundation in the fierce competitive market environment. Surgical operations using the water jet represent a potential instrument to enhance both surgical operations in favour of patient's life quality improvement and eventually general social and economic impact. In spite of considerable advance in the application of the water jet technology we are aware of the problems related to its application in clinical practice and thus we do believe that by the contribution a possible discussion focused on the field in question shall be initiated.

The results are valid for further investigation in order to rationalize the (re)implantation of femoral stems to reduce the thermal effect of bone cement. In such a way the biological potential of bone during surgery can be retained, and by removing the negative effect a patient can sooner return to normal life. The aim is to decrease costs and potential undesirable clinical impacts connected with their use. This scientific research work is based on the opportunity to apply water jet cutting technology. It comprises the outcomes of exploration and opportunities for the utilization of water jet cutting technology and pulsating water jet for the purpose of the responsible and profitable introduction of such technology in orthopaedic practice.

\section{Acknowledgements}

This work was supported by the Slovak Research and Development Agency under contract no. APVV-207-12. Activities were supported by Danube Region Project Fund project: WORTH 15_PA07-C1. Experiments were conducted with the support of the project of the Institute of Clean Technologies for Mining and Utilization of Raw Materials for Energy Use-Sustainability Program, reg. no. LO1406 financed by the Ministry of Education, Youth and Sports of the Czech Republic, and with support for the long-term conceptual development of the research institution RVO: 68145535.

\section{References}

[1] May, T. C.; Krause, W. R.; Preslar, A. J.; Smith, M. J.; Beaudoin, A. J.; Cardea, J. A. Use of high-energy shock waves for bone cement removal. // J Arthroplasty. 5, 1 (1990), pp. 19-27. DOI: 10.1016/S0883-5403(06)80005-7

[2] Weinstein, J. N.; Oster, D. M.; Park, J. B.; Park, S. H.; Loening, S. The effect of the extracorporeal shock wave lithotriptor on the bone-cement interface in dogs. // Clin Orthop. 235, (1988), pp. 261-267. DOI: 10.1097/00003086198810000-00025

[3] Schreurs, B. W.; Bierkens, A. F.; Huiskes, R.; Hendrikx, A. J.; Slooff, T. J. The effect of the extracorporeal shock wave lithotriptor on bone cement. // J Biomed Mater Res. 25, No. 2(1991), pp. 157-164. DOI: 10.1002/jbm.820250203

[4] Braun, W.; Claes, L.; Ruter, A.; Paschke, D. Effect of shock waves on the strength of connection between bone and polymethylmethacrylate. An in vitro study of human femur segments. // Z Orthop Ihre Grenzgeb. 130, 3(1992), pp. 236-243. DOI: 10.1055/s-2008-1040145

[5] Stranne, S. K.; Callaghan, J. J.; Fyda, T. M.; Fulghum, C. S.; Glisson, R. R.; Weinerth, J. L.; Seaber, A. V. The effect of extracorporeal shock wave lithotripsy on the prosthesis interface in cementless arthroplasty. Evaluation in a rabbit model. // J Arthroplasty. 7, 2(1992), pp. 173-179. DOl: 10.1016/0883-5403(92)90012-F

[6] Schmidt, J.; Nordmann, K. Removal of bone cement from the femoral canal using an acoustic emission-controlled milling device. // Med Biol Eng Comput. 32, 3(1994), pp. 258-260. DOI: 10.1007/BF02512520

[7] Schmidt, J.; Porsch, M.; Hackenbroch, M. H.; Koebke, J.; Brimmers, P. ModiWedintracorporeal lithotripsy for cement removal in hip prosthesis Exchange operationsexperimental principles. // Z Orthop Ihre Grenzgeb, 136, 1(1998), pp. 44-49. DOI: 10.1055/s-2008-1044650

[8] Chin, A. K.; Moll, F. H.; McColl, M. B.; Hoffman, K. J.; Wuh, H. C. An improved technique for cement extraction in revision total hip arthroplasty. // Contemp Orthop. 22, 3(1991), pp. 255-264.

[9] Schurman, D. J.; Maloney, W. J. Segmental cement extraction at revision total hip arthroplasty. // Clin Orthop. 285(1992), pp. 158-163. DOI: 10.1097/00003086-19921200000021

[10] Ekelund, A. L. Cement removal in revision hip arthroplasty. Experience with bonecement added to the cavity in 20 cases. // Acta Orthop Scand. 63, 5(1992), pp. 549-551. DOI: 10.3109/17453679209154735

[11] Jingushi, S.; Noguchi, Y.; Shuto, T.; Nakashima, T.; Iwamoto Y. A device for removal of femoral distal cement plug during hip revision arthroplasty: a highpowered drill 
equipped with a centralizer. // J Arthroplasty. 15, 2(2000), pp. 231-233. DOI: 10.1016/S0883-5403(00)90374-7

[12] Porsch, M.; Schmidt, J. Cement removal with an endoscopically controlled ballistically driven chiselling system. A new device for cement removal and preliminary clinical results. // Arch Orthop Trauma Surg. 121, 5(2001), pp. 274-277. DOI: 10.1007/s004020000233

[13] Holmenschlager, F.; Piatek, S.; Halm, J. P.; Winckler, S. Retrograde intramedullary nailing of femoral shaft fractures. A prospective study // Unfallchirurg. 105, (2002), pp. 1100-1108. DOI: 10.1007/s00113-002-0453-0

[14] Piatek, S.; Westphal, T.; Holmenschlager, F.; Becker, R.; Winckler, S. Retrograde cement removal in periprosthetic fractures following hip arthroplasty. // Arch Orthop Trauma Surg. 127, 7(2007), pp. 581-585. DOI: 10.1007/s00402-0060249-8

[15] Toth, K.; Sisak, K.; Nagy, J.; Mano, S.; Csernatony, Z; Retrograde stem removal in revision hip surgery: removing a loose or broken femoral component with a retrograde nail. // Archives of Orthopaedic and Trauma Surgery. 130, 7(2010), pp. 813-818. DOI: 10.1007/s00402-010-1063-x

[16] Szendrői, M.; Tóth, K.; Kiss, J.; Antal, I.; Skaliczki G. Retrograde genocephalic removal of fractured or immovable femoral stems in revision hip surgery. // Hip Int. 20, 1(2010), pp. 34-37.

[17] Witt, A. N.; Hackenbroch, M. H. Therapeutic approaches to implant loosening in total hip arthroplasty. // Z Orthop Ihre Grenzgeb. 114, 3(1976), pp. 330-341.

[18] Hackenbroch, Jr. M. H. Opportunities and limitations of exchange of hip and knee joint prostheses. // Z Orthop Ihre Grenzgeb. 117, 4(1979), pp. 457-460.

[19] Weber, B. G. Total hip replacement revision surgery: Surgical technique and experience. // In: Hip, E.A. Salvati, (Ed.), 3-14, Proceedings of the 9th Open Scientific Meeting of the Hip Society.

[20] Tyer, H. D.; Huckstep, R. L.; Stalley, P. D. Intraluminal allograft restoration of the upper femur in failed total hip arthroplasty. // Clin Orthop Relat Res. 224, (1987), pp. 2632. DOI: $10.1097 / 00003086-198711000-00004$

[21] Moreland, J. R., Marder, R., Anspach, W. E Jr. The window technique for the removal of broken femoral stems in total hip replacement. // Clin Orthop Relat Res. 212, (1986), pp. 245-249. DOI: 10.1097/00003086-19861100000026

[22] Younger, T. I. et al. Extended proximal femoral osteotomy: a new technique for femoral revision arthroplasty. // Journal of Arthroplasty. 10, 3(1995) pp. 329-338. DOI: 10.1016/S0883-5403(05)80182-2

[23] Chen, W. M. et al. Extended slide trochanteric osteotomy for revision total hip arthroplasty. // The Journal of Bone and Joint Surgery. American, 82, 9(2000), pp. 1215-1219.

[24] Miner, T. M.; Momberger, N. G.; Chong, D.; Paprosky, W. L. The extended trochanteric osteotomy in revision hip arthroplasty: a critical review of 166 cases at mean 3-year, 9-month follow-up.// Journal of Arthroplasty. 16, 8(2001), pp. 188-194. DOI: $10.1054 /$ arth.2001.29385

[25] Khanna, G.; Bourgeault, C. A.; Kyle, R. F. Biomechanical comparison of extended trochanteric osteotomy and slot osteotomy for femoral component revision in total hip arthroplasty // Clin Biomech. 22, 5(2007), pp. 599-602. DOI: 10.1016/j.clinbiomech.2006.02.002

[26] Goto, K. et al. Clinical and radiological evaluation of revision hip arthroplasty using the cement-incement technique. // The Journal of Bone and Joint Surgery. British, 90, 8(2008), pp. 1013-1018. DOI: 10.1302/0301620X.90B8.20388

[27] Braren, B.; Srinivasan, R.; Hannon, G.; Zickel, R. Excimer laser as a surgical tool for the removal of bone cement during revision of total hip arthroplasty. 4-5(1987) pp. 7475 .
[28] Scholz, C.; Matthes, M.; Kar, H.; Boenick, U. Bone cement removal with the laser. [Die Knochenzemententfernung mit dem Laser] // Biomedizinische Technik, 36, 5(1991), pp. 120-128. DOI: $10.1515 / \mathrm{bmte} .1991 .36 .5 .120$

[29] Caillouette, J. T.; Gorab, R. S.; Klapper, R. C.; Anzel, S. H. Revision arthroplasty facilitated by ultrasonic tool cement removal. Part I: In vitro evaluation. // Orthop Rev. 20(1991), pp. 353-357.

[30] Caillouette, J. T.; Gorab, R. S.; Klapper, R. C.; Anzel, S. H. Revision arthroplasty facilitated by ultrasonic tool cement removal. Part II: histologic analysis of endosteal bone after cement removal. // Orthop Rev. 20, 5(1991), pp. 435-440.

[31] deSteiger, Pandey, R.; McLardy-Smith P. Ultrasonically driven tools. // J Arthroplasty. 11(1996), pp.120-121. DOI: 10.1016/S0883-5403(96)80172-0

[32] Smith, P. N.; Eyres, K. S. Safe removal of massive intrapelvic cement using ultrasonic instruments. // J Arthroplasty. 14(1999), pp. 235-238. DOI: 10.1016/S08835403(99) $90133-X$

[33] Honl, M. et al. The Use of Water-Jetting Technology in Prostheses Revision Surgery - First Results of Parameter Studies on Bone and Bone Cement. // J Biomed Mater Res. 53, 6(2000), pp. 781-790. DOI: 10.1002/10974636(2000)53:6<781::AID-JBM20>3.0.CO;2-G

[34] Honl, M.; Rentzsch, R.; Lampe, F.; Müller, V.; Dierk, O.; Hille, E.; Louis, H.; Morlock, M. Water jet cutting for bones and bone cement-parameter study of opportunities and limits of a new method. // Biomed Tech Berlin. 45(2000), pp. 222-227. DOI: 10.1515/bmte.2000.45.9.222

[35] Honl, M.; Schwieger, K.; Carrero, V.; Rentzsch, R.; Dierk, O.; Dries, S.; Morlock, M. The pulsating water jet for selective removal of bone cement during revision arthroplasty. [Der gepulste Wasserstrahl zur selektiven Knochenzemententfernung in der Revisionsendoprothetik] Biomedizinische Technik. 48, 10(2003), pp. 275-280. DOl: 10.1515/bmte.2003.48.10.275

[36] Honl, M. et al. The water jet as a new tool for endoprosthesis revision surgeryan in vitro study on human bone and bone cement. // Biomed Mater Eng. 13, 4(2003), pp. 317-25.

[37] Kamineni, S.; An, K.; Morrey, B. F. Methods of removing excess bone cement. // Orthopedics. 30, 1(2007), pp. 12-16.

[38] Oliver, W. C.; Pharr, G. M. An improved technique for determining hardness and elastic modulus using load and displacement sensing indentation experiments. // J. Mater. Res. 7, 6(1992), pp. 1564-1583. DOI: 10.1557/JMR.1992.1564

\section{Authors' addresses}

\section{Sergej Hloch}

Institute of Geonics of the CAS, v. v. i.

Studentská 1768, 70800 Ostrava-Poruba, Czech Republic

Faculty of Manufacturing Technologies

of Technical University of Košice with a seat in Prešov Bayerova 108001 Prešov

Slovak Republic

E-mail: hloch.sergej@gmail.com

\section{Josef Foldyna}

Institute of Geonics of the CAS, v. v. i.

Studentská 1768, 70800 Ostrava-Poruba, Czech Republic

E-mail: josef.foldyna@ugn.cas.cz

\section{Frank Pude}

Inspire AG (ETH Zurich),

Zurich, Switzerland

E-mail: pude@inspire.ethz.ch

\section{Ján Kl'oc}

Department of Orthopaedics 
J. A. Reiman Faculty Hospital with Policlinics in Prešov

Slovak Republic

E-mail:kloc@fnsppresov.sk

\section{Michal Zeleňák}

Institute of Geonics of the CAS, v. v. i.

Studentská 1768, 70800 Ostrava-Poruba, Czech Republic

E-mail:michal.zelenak@ugn.cas.cz

\section{Pavol Hvizdoš}

Slovak Academy of Sciences,

Institute of Material Research,

Watsonova 47

04001 Košice, Slovak Republic

E-mail: hvizdosp@gmail.com

\section{Jiř́ Ščučka}

Institute of Geonics of the CAS, v. v. i.

Studentská 1768, 70800 Ostrava-Poruba, Czech Republic

E-mail: jiri.scucka@ugn.cas.cz

\section{Igor Smolko}

Department of Orthopaedics

J. A. Reiman Faculty Hospital with Policlinics in Prešov

Slovak Republic

E-mail: smolko@fnsppresov.sk

\section{Peter Monka}

Faculty of Manufacturing Technologies

of Technical University of Košice with a seat in Prešov

Bayerova 108001 Prešov

Slovak Republic

E-mail: peter.monka@tuke.sk

\section{Dražan Kozak}

Mechanical Engineering Faculty in Slavonski Brod

J. J. Strossmayer University of Osijek

Trg Ivane Brlić-Mažuranić 2

HR-35000 Slavonski Brod, Croatia

E-mail: dkozak@sfsb.hr

\section{Aleksandar Sedmak}

Innovation Centre of Faculty of Mechanical Engineering, University of Belgrade,

Kraljice Marije 16, 11141 Belgrade

E-mail: aleksandarsedmak@yahoo.com

\section{Emilia Mihalčinová}

Department of Orthopaedics

J. A. Reiman Faculty Hospital with Policlinics in Prešov

Slovak Republic 